\title{
Analysis of Current Trends and Prospects of Tourism Development in Uzbekistan
}

\author{
Alimova Mashhura Toirkhonovna ${ }^{1}$, Bobur Sobirov $^{2}$, Narbayev Alisher Erkinjonovich ${ }^{3}$ \\ alimovamashhura@mail.ru1, mrbobursobirov@gmail.com²
}

Silk Road International Tourism University, Uzbekistan ${ }^{1}$ Samarkand Institute of Economics and Service, Uzbekistan ${ }^{2}$, Tashkent State Technical University named after Islam Karimov, Uzbekistan $^{3}$

\begin{abstract}
The article examines the current trends in the development of tourism in the Republic of Uzbekistan, using the methods of comparative analysis of the dynamics of indicators. The experience of the Republic of Uzbekistan of reforming the tourism industry into a locomotive for the accelerated development of the national economy on the basis of significant factors in the development of this field, such as simplifying tourist formalities, improving the tourism infrastructure, creating favorable conditions for conducting the tourism business, expanding the range of tourism services, improving the quality of services provided and diversifying the tourism industry, was studied. product, increasing the investment attractiveness of tourist regions and the quality of preparation for firewood, as well as appropriate use of the country's tourism potential. Based on the analysis of development trends in the tourism sector in the country, the results of these reforms are substantiated. The forecast data of the main indicators of the development of the tourism sector in the country are presented. Based on the results of the analysis, recommendations are given on the further development of the tourism sector in Uzbekistan.
\end{abstract}

Keywords: tourism, tourism market, international tourism, development trends, visitors, tourism infrastructure, international tourist arrivals, model, forecasting

\section{Pendahuluan}

Industri pariwisata modern adalah produsen global terbesar dari produk dunia bruto dan sumber utama lapangan kerja - industri ini merupakan bagian penting dari indikator dunia. Menurut World Travel and Tourism Council, lebih dari 318,8 juta orang, atau 10\% dari total lapangan kerja dunia, dipekerjakan di sektor pariwisata pada tahun 2018. Selain itu, saat ini menyumbang 10,4\% dari PDB global (dengan mempertimbangkan dampak langsung dan tidak langsung dari pariwisata terhadap ekonomi global), 29\% dari ekspor jasa global (1,5 triliun dolar AS) dan 7\% dari ekspor barang dan jasa dunia, serta setiap 10 pekerjaan yang diciptakan dalam ekonomi global. Menjadi katalisator yang kuat untuk pengembangan sosial-ekonomi masing-masing negara dan kawasan, pariwisata memberikan pemasukan mata uang asing dan investasi, berkontribusi pada pertumbuhan industri terkait yang cepat, membantu menyelesaikan masalah ketenagakerjaan, dan meningkatkan reputasi negara di komunitas dunia. Penting untuk dicatat bahwa kekuatan ekonomi pariwisata sebagian besar didasarkan pada efek pengali, yang berskala sangat besar dalam pariwisata. Berkat efek animasi, satu tempat kerja dalam pariwisata menciptakan tujuh pekerjaan baru di industri dan sektor lain yang terkait dengan pariwisata oleh rantai koperasi. Karena itu, pariwisata dapat memberikan 
awal ke tahap kualitatif baru dalam pengembangan banyak daerah di negara ini, terutama dengan peluang rekreasi yang luar biasa.

Uzbekistan tidak terkecuali, yang memiliki potensi wisata dan rekreasi yang besar, yang memiliki 7,4 ribu benda warisan budaya, 209 di antaranya ada di empat kota museum "Ichan kala di kota Khiva", "pusat bersejarah kota Bukhara ", Kota-kota pusat bersejarah Shakhrisabz "dan“ Kota Samarkand "termasuk dalam daftar Situs Warisan Dunia UNESCO. Namun, di Uzbekistan pariwisata belum mencapai tingkat pengembangan yang memadai untuk kemampuan potensinya.

Hari ini, setelah memberi perhatian pada percepatan pengembangan sektor pariwisata, salah satu tujuan dan prioritas kebijakan negara di bidang pariwisata untuk jangka menengah didefinisikan sebagai "memberikan pariwisata status sektor sektor strategis ekonomi, mengubah ini. industri menjadi alat yang kuat untuk pembangunan berkelanjutan, transformasi struktural dan diversifikasi ekonomi, yang harus menjadi lokomotif untuk percepatan pembangunan terpadu semua wilayah dan industri terkait. ”

Mengingat bahwa tujuan global untuk setiap unit teritorial adalah pertumbuhan ekonomi yang berkelanjutan dan jangka panjang, dan industri pariwisata adalah sektor strategis ekonomi nasional pada tahap reformasi sosial-ekonomi saat ini di Republik Uzbekistan, kami menganggapnya relevan untuk mempelajari tren dan prospek utama untuk pengembangan pariwisata di negara ini.

Pariwisata sebagai fenomena massa membutuhkan penilaian kuantitatif dan kualitatif. Studi tentang tren dan pengembangan ramalan untuk pengembangan pariwisata internasional, baik di dunia maupun di masing-masing negara dan wilayah, didasarkan pada statistik pariwisata, yang dikelola di negara-negara oleh berbagai badan antar negara.

Hanya dengan data yang memadai dan memadai untuk mendapatkan statistik yang andal dapat dilakukan berbagai jenis analisis industri pariwisata. Ini diperlukan untuk menilai berbagai aspek pariwisata, memastikan dan meningkatkan kebijakan dan proses pengambilan keputusan.

Di tingkat internasional, sejumlah dokumen telah diadopsi mengenai metodologi dan metodologi statistik pariwisata. Selama bertahun-tahun, mereka membaik, dan digunakan untuk menghitung kontribusi nyata pariwisata bagi pengembangan ekonomi nasional. Salah satu dokumen terbaru tentang waktu adopsi, dan yang berfungsi sebagai dasar untuk statistik pariwisata nasional di banyak negara, adalah Rekomendasi Internasional tentang Statistik Pariwisata 2008, yang disusun sesuai dengan keputusan yang diadopsi oleh Komisi Statistik PBB pada sesi ke tiga puluh lima, yang diadakan dari 2 hingga 5 Maret 2004.

Dokumen utama dalam statistik pariwisata internasional adalah laporan tahunan UNWTO "Sorotan Pariwisata UNWTO" dan laporan analitik World Tourism Barometer UNWTO, laporan regional tentang pariwisata inbound dan outbound, yang terutama menyediakan statistik berikut: jumlah kedatangan internasional pada umumnya dan secara terpisah menurut wilayah, dalam dinamika, sejak 1990; volume pengeluaran wisatawan pada umumnya dan secara terpisah berdasarkan wilayah, dalam dinamika, sejak 1990. Dokumen penting yang menentukan kontribusi pariwisata bagi perekonomian negara adalah laporan tahunan Dewan Perjalanan \& Pariwisata Dunia.

Di Republik Uzbekistan, pengumpulan informasi statistik dilakukan oleh Komite Negara Statistik dan telah disusun sejak 2005 dalam bentuk laporan tahunan "Buletin Statistik, sementara indikator utama pengembangan pariwisata di Republik Uzbekistan telah diilustrasikan dengan indikator utama. "Seperti yang jelas dari tanggal rilis koleksi ini, panjang dinamika statistik yang diberikan dalam koleksi ini tidak memungkinkan untuk memprediksi pengembangan pariwisata di Republik Uzbekistan untuk jangka waktu yang lama. Kesulitan 
dalam memperoleh statistik pariwisata terletak pada kenyataan bahwa indikator-indikatornya tersebar di berbagai bentuk pelaporan statistik dan membutuhkan sistematisasi yang mendalam dalam pengumpulan dan analisis indikator-indikator ini. Juga, pengumpulan dan sistematis data statistik tentang pariwisata di republik ini dilakukan oleh Komite Negara untuk Pengembangan Pariwisata Republik. Spesialis dalam bidang ini mencatat bahwa sistem statistik pariwisata yang ada di Republik Uzbekistan masih jauh dari sempurna. Meskipun dalam beberapa tahun terakhir telah ada peningkatan dalam akuntansi statistik kegiatan wisata di negara kita, banyak masalah tetap tidak terselesaikan. Studi kami didasarkan pada indikator pengembangan pariwisata di dunia dan di Republik Uzbekistan, yang diberikan dalam dokumen yang ditunjukkan di atas.

Dengan demikian, hari ini studi tentang tren pengembangan pariwisata merupakan aspek penting, baik secara internasional maupun di tingkat negara dan wilayah individu. Masalah ini di seluruh dunia saat ini sedang dipelajari secara aktif.

Studi-studi ini dikhususkan untuk studi pengembangan pariwisata di seluruh dunia, di tingkat negara atau wilayah tertentu, segmen terpisah dari pasar layanan pariwisata, elemen terpisah dari sistem industri pariwisata, jenis organisasi pariwisata yang berbeda, dll. .

Diketahui bahwa menarik wisatawan asing ke negara itu bergantung pada banyak faktor berbeda: ekonomi, politik, dan lingkungan dan, tentu saja, dikaitkan dengan masalah keselamatan wisatawan dan tingkat pengembangan layanan. Ini adalah, pertama-tama, kualitas layanan untuk wisatawan asing di hotel, transportasi, dan perusahaan wisata dan perjalanan dan lembaga budaya dan hiburan, tingkat layanan informasi dan banyak lagi.

Berdasarkan pernyataan-pernyataan ini, sejumlah besar studi telah dikhususkan untuk menilai dampak faktor sosial, ekonomi, politik dan alam pada tren pengembangan pariwisata [1] di wilayah tertentu di dunia, khususnya dampak peristiwa seperti serangan 11 September 2001 [2]; tindakan teroris; krisis keuangan dan ekonomi 2008 [2] [3], Olimpiade 2004, gempa bumi dan tsunami [4]; dampak pembatasan visa pada pengembangan pariwisata, dll. Peristiwa ini tidak dapat diprediksi sebelumnya; oleh karena itu, mereka berfungsi sebagai penghambat peramalan jangka panjang. Masalah peramalan pengembangan pariwisata baik di seluruh dunia dan pada skala regional telah dipelajari oleh peneliti yang berbeda menggunakan metode analisis data yang berbeda dan analisis kekurangan metode yang digunakan dalam studi ini dan proposal metode peramalan dalam situasi krisis. Kompleksitas peramalan kegiatan ekonomi di masa depan, terutama di saat ketidakpastian, adalah pertanyaan yang telah lama mengganggu para peramal

Tetapi dalam kasus yang berlawanan, dengan waktu normal atau tenang, peramalan adalah alat yang berguna untuk merencanakan dan memprediksi arah kegiatan pariwisata di masa depan dan secara luas digunakan oleh pemerintah untuk merumuskan kebijakan industri [5] [6] [7].

Untuk peramalan, sebagai suatu peraturan, serangkaian metode analitik tertentu digunakan, berdasarkan pada analisis arus wisatawan, serta sejumlah faktor yang mempengaruhi perkembangan industri ini.

Calantone, Benedetto, dan Bofanic, [8] membedakan antara empat bentuk peramalan. Peramalan eksplorasi mengekstrapolasi tren masa lalu menggunakan regresi dan teknik serupa dan didasarkan pada asumsi tentang hubungan antar variabel. Saat meramalkan pengembangan pariwisata di Republik Uzbekistan, kami menggunakan metode ekstrapolasi serangkaian dinamika. 


\section{Metode}

Mempelajari dan menganalisis serangkaian dinamika, para peneliti telah lama berusaha untuk memprediksi perilaku seri di masa depan berdasarkan fitur yang terungkap dari perubahan fenomena di masa lalu, dan mencoba membuat berbagai ramalan dengan mengekstrapolasi seri (memperluas seri).

Ekstoropolisasi sejumlah dinamika dapat dilakukan dengan berbagai cara. Tetapi terlepas dari metode yang digunakan, setiap ekstrapolasi semacam itu perlu didasarkan pada asumsi bahwa pola (kecenderungan) dari perubahan dalam fenomena yang diteliti, yang diungkapkan untuk periode waktu tertentu di masa lalu, akan tetap untuk waktu yang terbatas di masa depan. Oleh karena itu, setiap ramalan dalam bentuk ekstrapolasi suatu seri harus didahului oleh studi menyeluruh dari serangkaian panjang dinamika, yang akan memungkinkan kita untuk menentukan tren perubahan. Dan karena, pada kenyataannya, tren pembangunan, pada gilirannya, dapat berubah, data yang diperoleh dengan mengekstrapolasi serangkaian harus dianggap sebagai jenis penilaian probabilistik.

Ada beberapa metode ekstrapolasi serangkaian dinamika yang membantu memprediksi indikator tertentu untuk periode waktu tertentu di masa depan. Misalnya, Anda dapat memperkirakan seri berdasarkan pada menyelaraskannya sesuai dengan formula analitis tertentu. Mengetahui persamaan untuk level teoretis dan mensubstitusi nilai t di luar seri yang dipelajari ke dalamnya, kita dapat menghitung probabilitas $\mathrm{y}_{-}^{-} \mathrm{t}$ untuk data $\mathrm{t}$.

Tujuan utama dari analisis deret waktu adalah untuk menciptakan ramalan dan memprediksi masa depan. Prakiraan ini didasarkan pada model tertentu. Model ini adalah sistem persamaan yang memungkinkan Anda untuk mendapatkan serangkaian set data buatan yang terkait dengan kategori deret waktu. Jika model yang digunakan adalah benar sehubungan dengan data yang sedang dipelajari, maka pengamatan di masa depan dengan probabilitas, misalnya, $95 \%$ termasuk dalam batas-batas ini.

Cara yang lebih maju dalam memproses deret waktu untuk menetapkan tren pengembangan utama adalah perataan menurut rumus analitik (atau perataan analitik). Dengan metode ini, setiap level aktual $\mathrm{y}_{\mathrm{t}}$ dianggap sebagai jumlah dari dua istilah $\mathrm{y}_{\mathrm{t}}=\mathrm{f}(\mathrm{t})+\varepsilon_{\mathrm{t}}$, dimana $\mathrm{f}(\mathrm{t})$ - komponen sistematis yang mencerminkan tren dan diekspresikan oleh persamaan tertentu, dan $\varepsilon_{t}-$ nilai komponen acak. Masalah pelurusan dikurangi untuk menentukan jenis fungsi berdasarkan data aktual. $\hat{y}_{t}=f(t)$, menemukan parameternya sesuai dengan data empiris dan menghitung persamaan "teoritis" menggunakan rumus yang ditemukan. Rumus paling sederhana yang mengekspresikan tren pengembangan (tren) diberikan pada tabel-1.

Kualitas model, secara keseluruhan, dan sesuai dengan parameter individu dievaluasi menggunakan kriteria Fisher. Untuk ini, diperoleh, yaitu, nilai aktual dari kriteria Fisher dibandingkan $\left(\mathrm{F}_{\text {fact }}\right)$ menemukan parameternya sesuai dengan data empiris dan menghitung persamaan "teoritis" menggunakan rumus yang ditemukan. Rumus paling sederhana yang mengekspresikan tren pengembangan (tren) diberikan pada tabel-1.

Kualitas model, secara keseluruhan, dan sesuai dengan parameter individu dievaluasi menggunakan kriteria Fisher.

Untuk ini, diperoleh, yaitu, nilai aktual dari kriteria Fisher dibandingkan $\left(\mathrm{F}_{\text {table }}\right)$. $\mathrm{F}_{\text {fact }}$ ditentukan dari rasio faktor dan varian residual yang dihitung untuk satu derajat kebebasan:

$$
F_{\text {факт }}=\frac{\sum(\hat{y}-\bar{y})^{2} / m}{\sum(y-\hat{y})^{2} /(n-m-1)}=\frac{R^{2}}{1-R^{2}}(n-2),
$$

dimana:

$\mathrm{n}$ - jumalah observasi; 
$\mathrm{m}$ - jumlah parameter dengan factor $\mathrm{x}$.

$\mathrm{F}$ tabular - ini adalah nilai maksimum kriteria di bawah pengaruh faktor acak dengan derajat kebebasan saat ini dan tingkat signifikansi " $\alpha$ ". Level signifikansi " $\alpha$ " - probabilitas untuk tidak menerima hipotesis, asalkan itu benar. Biasanya " $\alpha$ " diasumsikan 0,05 atau 0,01.

Jika $\mathrm{F}_{\text {table }}>\mathrm{F}_{\text {fact }}$ maka statistik non-signifikansi model diakui, bukan keandalan persamaan regresi.

Nilai tabel uji Fisher dihitung sebagai berikut:

a. tentukan $\mathrm{k} 1$, yang sama dengan jumlah faktor (m). Misalnya, dalam model satu faktor (model regresi berpasangan) $\mathrm{k} 1=1$.

b. menentukan $\mathrm{k} 2$, yang ditentukan oleh rumus n-m-1, di mana $\mathrm{n}$ adalah jumlah pengamatan, $\mathrm{m}$ adalah jumlah faktor. Misalnya, dalam model satu faktor, $\mathrm{k} 2=\mathrm{n}-2$.

c. di persimpangan kolom $\mathrm{k} 1$ dan baris $\mathrm{k} 2$ menemukan nilai kriteria Fisher.

Tabel 1. Forecasting Models

\begin{tabular}{|l|l|l|}
\hline № & Analytical view & Function \\
\hline 1 & $y=\mathrm{b}_{0}+\mathrm{b}_{1}{ }^{\times \mathrm{t}}$ & Linear \\
\hline 2 & $y=\mathrm{b}_{0}+\mathrm{b}_{1} \ln (\mathrm{t})$ & Logarithmic \\
\hline 3 & $y=\mathrm{b}_{0}+\mathrm{b}_{1} / \mathrm{t}$ & Feedback \\
\hline 4 & $y=\mathrm{b}_{0}+\mathrm{b}_{1} \mathrm{t}+\mathrm{b}_{2} \mathrm{t}^{2}$ & Quadratic \\
\hline 5 & $y=\mathrm{b}_{0}+\mathrm{b}_{1} \mathrm{t}+\mathrm{b}_{2} \mathrm{t}^{2}+\mathrm{b}_{3} \mathrm{t}^{3}$ & Cubic \\
\hline 6 & $y=\mathrm{b}_{0}{ }^{\mathrm{x}} \mathrm{b}_{1}{ }^{\mathrm{t}}$ & Compound \\
\hline 7 & $y=\mathrm{b}_{0}{ }^{\mathrm{x}} \mathrm{t}^{\mathrm{b} 1}$ & Power \\
\hline 8 & $y=\mathrm{e}^{\left(\mathrm{b} 0+\mathrm{b}^{1 / \mathrm{t}}\right.}$ & $\mathrm{S}$ \\
\hline 9 & $y=\mathrm{e}^{\left(\mathrm{b} 0+\mathrm{b}^{1} \mathrm{x}\right)}$ & Growth \\
\hline 10 & $y=\mathrm{b}_{0} \mathrm{e}^{\mathrm{b}{ }^{\times \mathrm{t}}}$ & Exponential \\
\hline
\end{tabular}

Karena, menyelaraskan deretan dinamika sesuai dengan rumus analitis, kami terutama menentukan tren, kadang-kadang disarankan untuk melakukan hal berikut saat meramalkan: dengan menyelaraskan deret tersebut dengan satu atau beberapa rumus lain dan menentukan tren, menemukan penyimpangan dari aktual tingkat dari yang selaras. Kemudian Anda dapat mencoba menentukan pola (tren) dari perubahan waktu penyimpangan ini, yaitu menemukan rumus Anda untuk perubahannya. Setelah itu, ekstrapolasi kedua baris, letakkan bersama-sama.

\section{Pembahasan}

2016-2019 ditandai oleh reformasi besar-besaran di sektor pariwisata Republik Uzbekistan. Selama periode terakhir, sekitar 56 peraturan hukum dan tindakan lain di bidang ini telah dikembangkan dan diadopsi (tabel-2). 
Table 2. Jumlah tindakan hukum normatif yang diadopsi selama 2016-2019 tentang mereformasi sektor pariwisata Republik Uzbekistan.

\begin{tabular}{|l|c|}
\hline \multicolumn{1}{|c|}{ Legal act } & Quantity \\
\hline \multicolumn{1}{|c|}{ Decisions of the Head of State } \\
\hline Decrees of the President of the Republic of Uzbekistan & 12 \\
\hline Resolutions of the President of the Republic of Uzbekistan & 13 \\
\hline Orders of the President of the Republic of Uzbekistan & 1 \\
\hline \multicolumn{1}{|c|}{ Government Decisions } \\
\hline $\begin{array}{l}\text { Resolutions of the Cabinet of Ministers of the Republic of } \\
\text { Uzbekistan }\end{array}$ \\
\hline $\begin{array}{l}\text { Orders of the Cabinet of Ministers of the Republic of } \\
\text { Uzbekistan }\end{array}$ & 21 \\
\hline \multicolumn{1}{|c|}{ Other documents } & 1 \\
\hline Join decision & \\
\hline
\end{tabular}

Reformasi ke arah ini mulai berbuah. Untuk periode 2010-2017, ekspor layanan wisata di Uzbekistan naik dua kali lipat dan berjumlah 546,9 juta dolar AS pada 2017, dan pada 2018 - 1041 juta dolar AS. Tingkat pertumbuhan tahunan rata-rata pengunjung asing hingga 2016 adalah 8 persen, pada 2017 - 32,7 persen dan melebihi 2,69 juta orang. Pada akhir 2018, sekitar 5,3 juta turis asing mengunjungi republik ini.

Pada ekonomi global modern, keadaan pariwisata sangat tergantung pada analisis mendalam yang tepat waktu tentang tren dan faktor-faktor pembangunan, serta kegiatan dan reformasi terkait yang tercermin dalam hasil mereka. Kami ingin menunjukkan pernyataan ini pada contoh Republik Uzbekistan.

Menurut analisis, pada tahun 2000, Uzbekistan hanya menyumbang 0,04 persen dari arus wisatawan internasional dan $0,006 \%$ dari total pendapatan dunia dari pariwisata internasional, yang sangat tidak berarti bagi negara dengan potensi wisata yang tinggi. Meskipun dari tahun 2000 hingga 2018, tren pertumbuhan positif dari indikator-indikator ini terlihat, jumlah indikator ini masing-masing adalah 0,4 dan 0,08 persen, dan melebihi nilai sebelumnya sebesar 10 kali lipat. Ini didasarkan pada kenyataan bahwa di Uzbekistan hari ini, memberikan perhatian khusus pada pengembangan terintegrasi industri pariwisata, langkah-langkah skala besar sedang diambil untuk menyederhanakan formalitas wisata, meningkatkan infrastruktur pariwisata, menciptakan kondisi yang menguntungkan bagi bisnis pariwisata, memperluas berbagai layanan wisata, meningkatkan kualitas layanan yang diberikan dan diversifikasi produk pariwisata.

Jumlah pengunjung asing yang tiba di Uzbekistan dalam beberapa tahun terakhir telah berkembang pesat (Gambar-1). Jadi, pada tahun 2017, 2690 ribu turis asing mengunjungi Republik Uzbekistan. Angka ini 32,7\% lebih tinggi dibandingkan dengan 2016, ketika jumlah kedatangan mencapai 2.027 ribu orang. Pada gilirannya, selama 2018, jumlah pengunjung asing berjumlah 5.346 ribu orang dan melampaui indikator periode yang sama di tahun 2017 sebesar $99 \%$. 


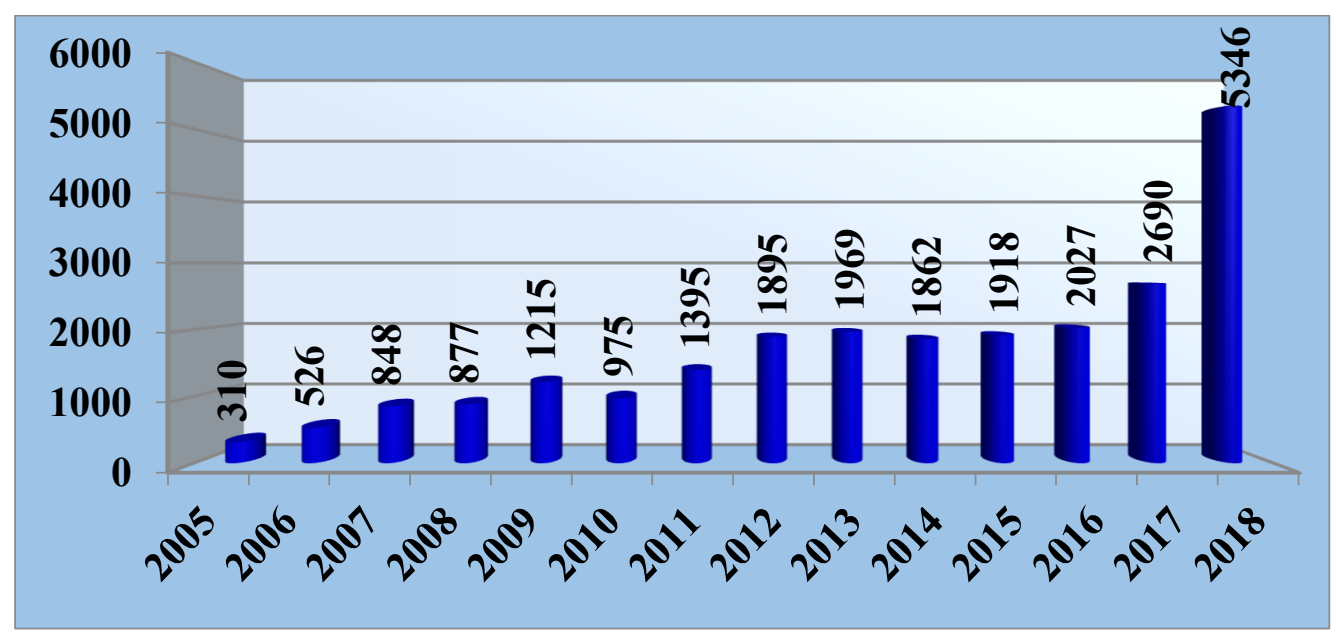

\section{Gambar. 1. Jumlah pengunjung asing yang datang ke Uzbekistan}

Pada Januari-Agustus 2019, 4324759 pengunjung dari 163 negara di dunia mengunjungi Republik Uzbekistan, yang 26,7\% lebih tinggi dari indikator yang sama pada 2018 (Gbr-1). Penyederhanaan prosedur visa untuk masuk ke Republik Uzbekistan berfungsi sebagai faktor penting untuk pengembangan pariwisata, yang memperluas struktur permintaan geografis untuk produk pariwisata nasional. $8 \%$ dari total jumlah pengunjung adalah pengunjung dari negaranegara non-CIS, indikator ini pada tahun 2018 adalah 7\%, yang merupakan hasil dari peningkatan jumlah pengunjung dari negara-negara non-CIS pada Januari-Agustus 2019 dibandingkan dengan yang sama periode pada 2018 sebesar 57,4\% (gambar. 2).

Faktor penting ketika memilih tujuan wisata adalah kurangnya hambatan bahasa dan adanya ikatan keluarga di tempat tinggal, yang mempengaruhi struktur geografis pengunjung ke negara kita. Lima pemimpin dalam pembentukan permintaan kunjungan adalah negaranegara CIS - Kazakhstan, Tajikistan, Kyrgyzstan, Federasi Rusia, dan Turkmenistan. Dalam daftar 20 negara donor utama, negara yang memimpin adalah Turki, Afghanistan, Cina, Korea Selatan, India, Jerman, Jepang, Italia, Prancis, Amerika Serikat, Inggris, Israel, Spanyol, Pakistan, dan Polandia (Gambar. 3).

Menurut statistik, tujuan perjalanan ke Uzbekistan untuk sebagian besar pengunjung adalah untuk mengunjungi teman dan kerabat. Bagian ini adalah $88,1 \%$ dari total jumlah pengunjung. Ini memengaruhi pembentukan struktur geografis permintaan untuk mengunjungi Republik Uzbekistan, 92\% pengunjung datang ke negara tersebut dari negara-negara CIS, dan juga menduduki posisi kepemimpinan puncak dalam kunjungan (Gambar 4-5). 


\section{Struktur geografis pengunjung yang memasuki}

Republik Uzbekistan pada Januari-Agustus 2018

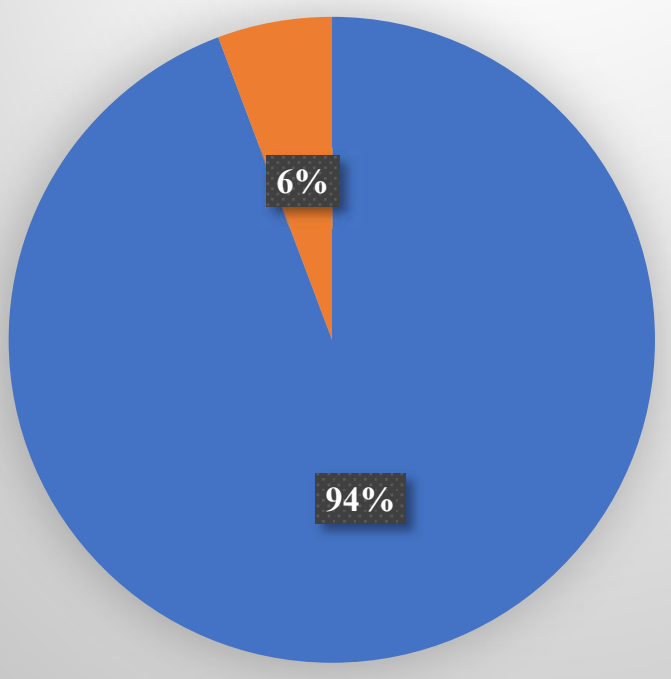

from the CIS countries

from far abroad

Struktur geografis pengunjung yang masuk ke Republik Uzbekistan pada Januari-Agustus 2019

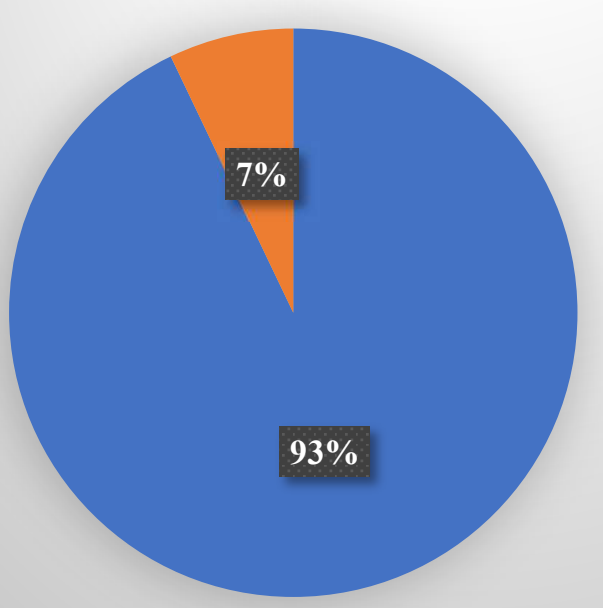

- from the CIS countries

a from far abroad

Gambar. 2. Struktur geografis pengunjung yang masuk ke Republik Uzbekistan pada Januari-Agustus 2019. 


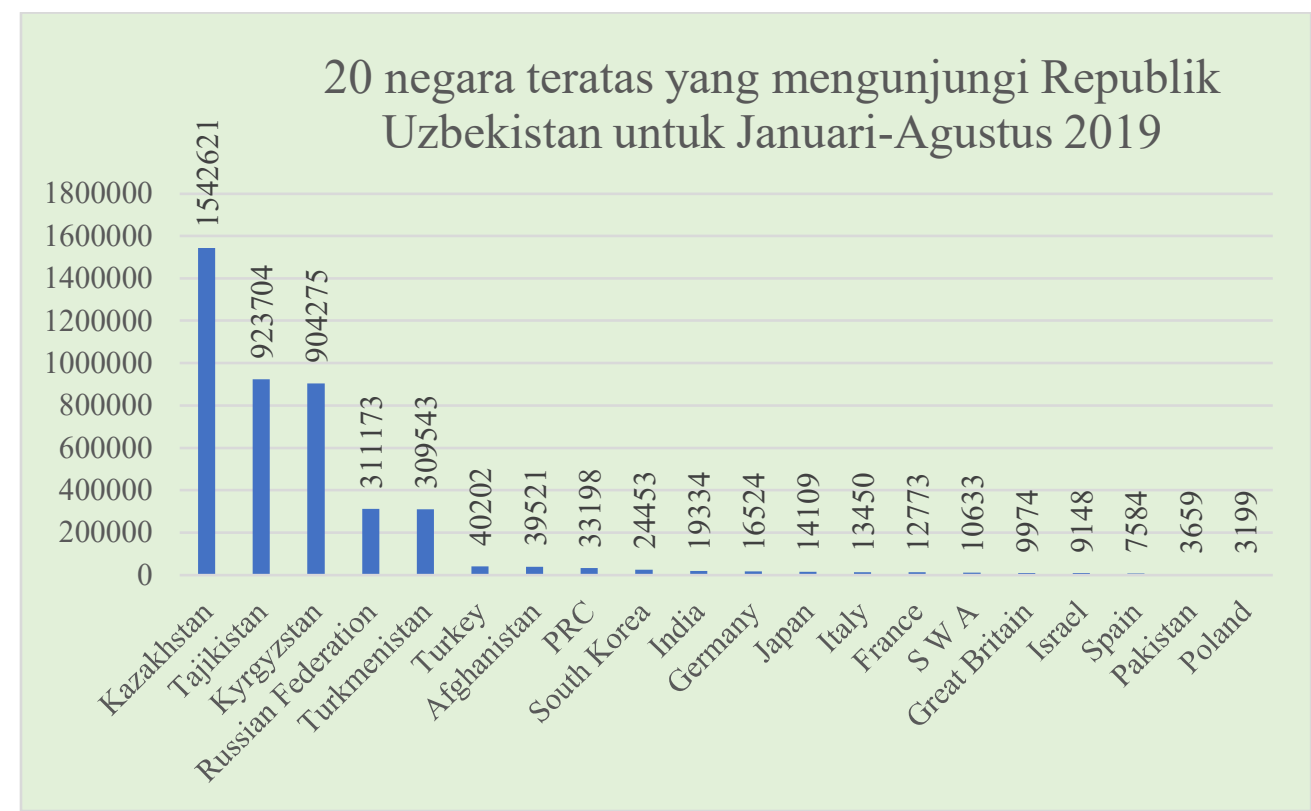

Gambar. 3. 20 negara teratas yang mengunjungi Republik Uzbekistan untuk JanuariAgustus 2019

Struktur geografis pengunjung yang tiba di Uzbekistan dari Januari hingga Agustus 2019

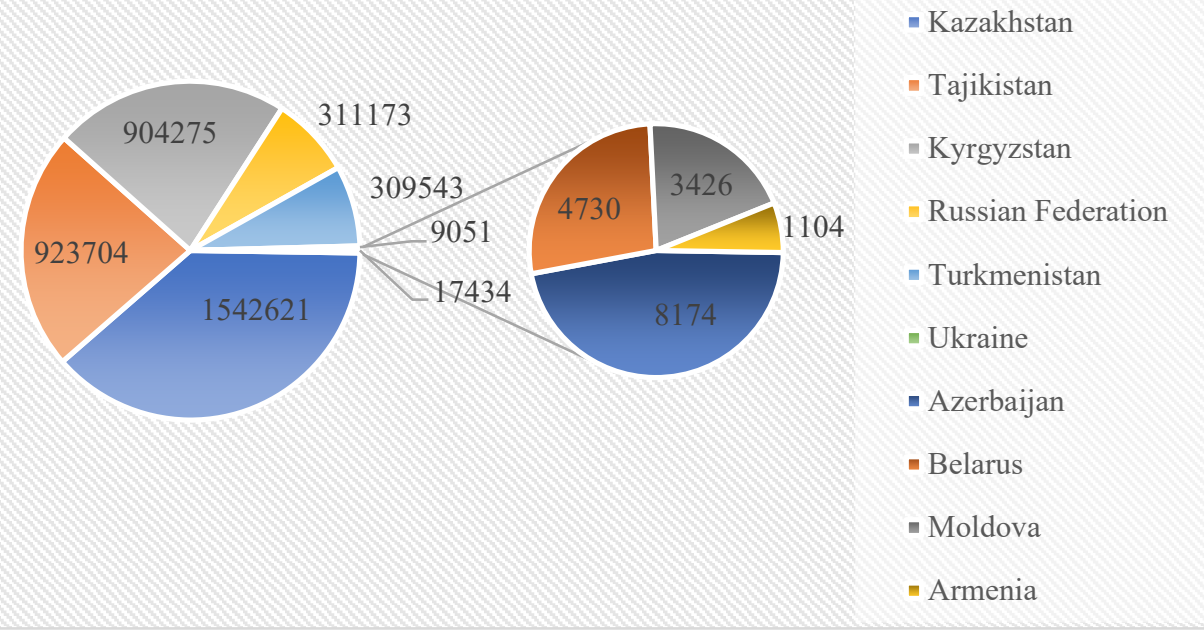

Gambar. 4. Struktur geografis pengunjung yang memasuki Republik Uzbekistan dari negara-negara CIS untuk Januari-Agustus 2019 


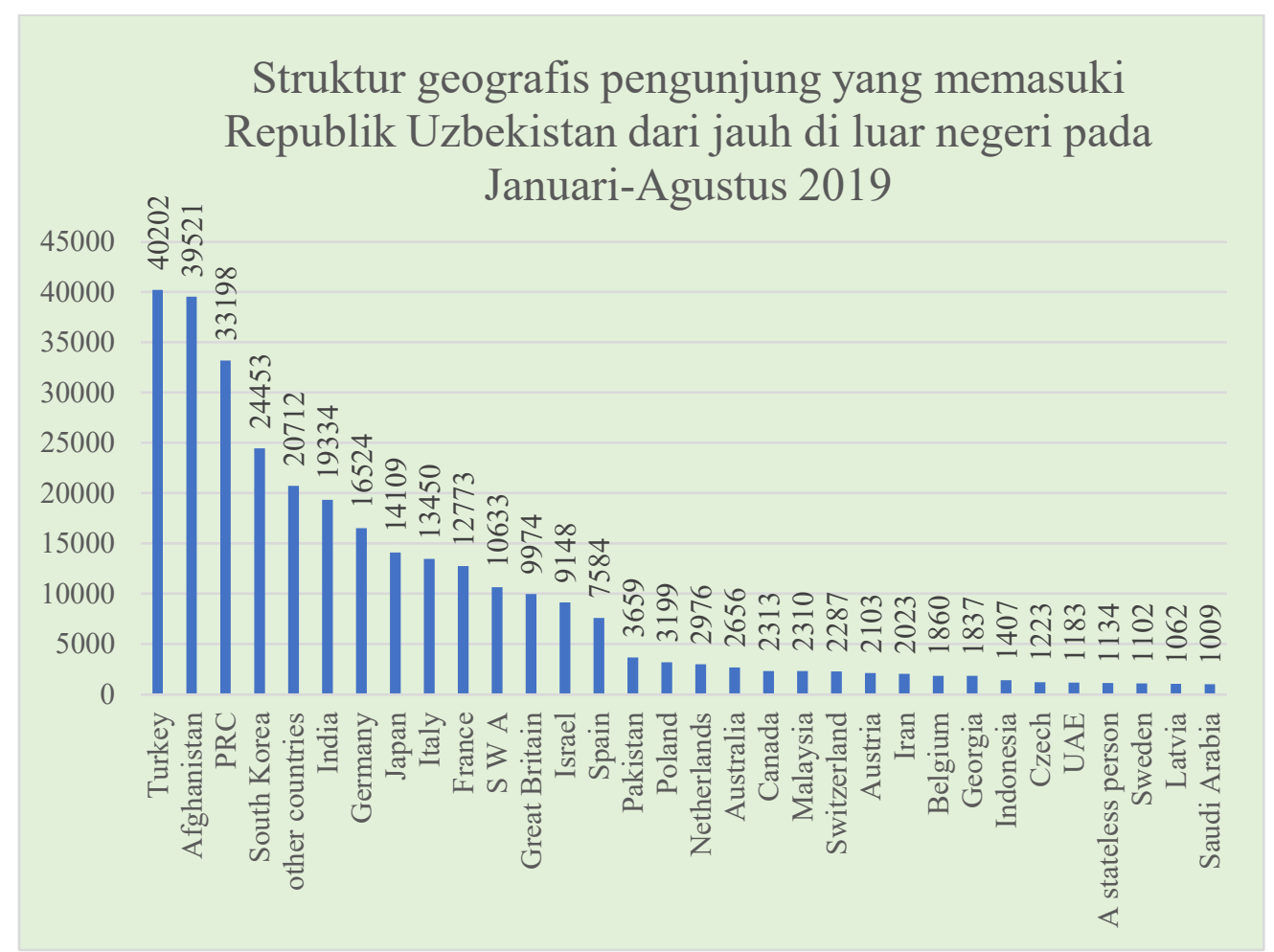

Gambar. 5. Struktur geografis pengunjung yang memasuki Republik Uzbekistan dari Januari hingga Agustus 2019

Kelompok usia 31 hingga 55 tahun adalah jumlah pengunjung terbesar. Berikut ini adalah kategori umur hingga 30 tahun dan dari 56 tahun ke atas (Gambar. 6).

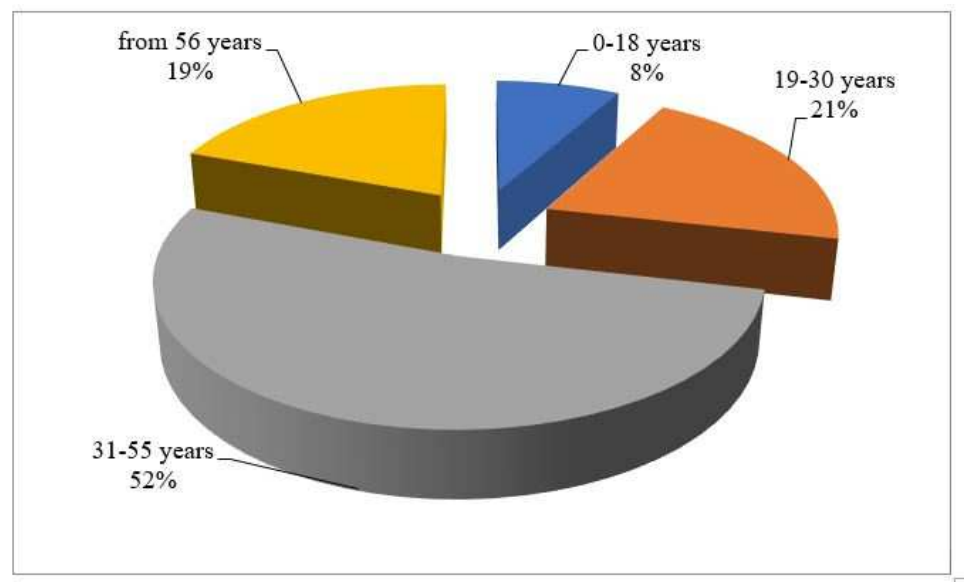

Gambar 6. Struktur usia konsumen asing dari produk pariwisata nasional pada tahun 2018. 
Meskipun studi yang dilakukan pada 2011 menunjukkan bahwa permintaan di segmen pasar pariwisata nasional ini dibentuk oleh pengunjung berusia 61 tahun ke atas (Gambar. 7). Pekerjaan berskala besar untuk mendiversifikasi produk pariwisata nasional adalah hasil dari peremajaan struktur permintaan untuk produk jenis ini.

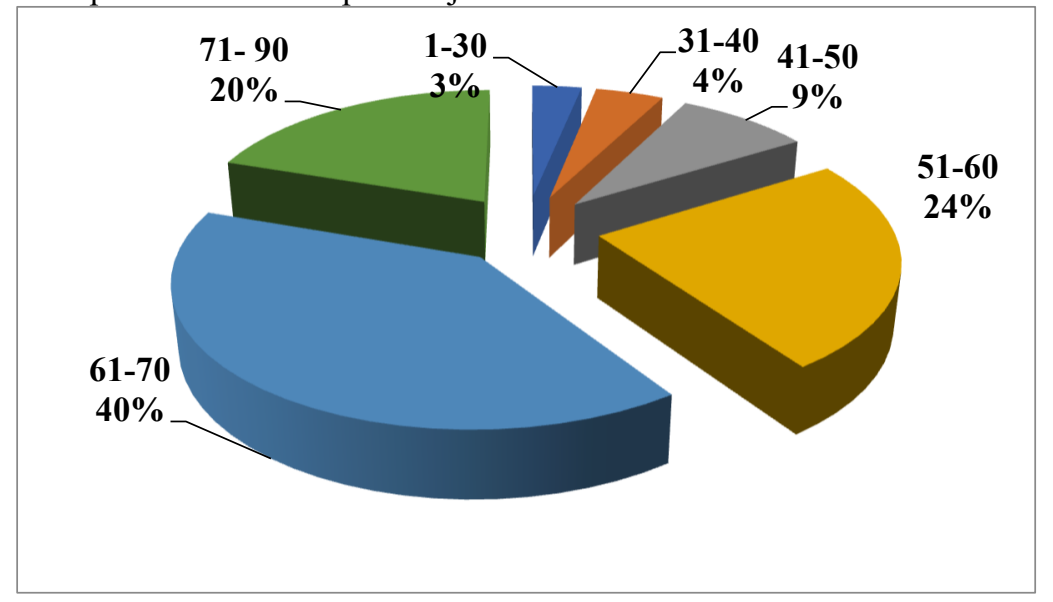

Gambar 7. Struktur usia konsumen asing dari produk pariwisata nasional pada tahun 2011.

Secara terpisah, perlu dicatat reformasi yang sedang berlangsung untuk pengembangan pariwisata domestik, yang memastikan peningkatan pasokan dengan merangsang permintaan domestik di pasar pariwisata. Pada tahun 2018, dengan keputusan Presiden, program pertama disetujui untuk pengembangan pariwisata domestik "Uzbekistan bilab sa caxat uil!".

Untuk tujuan ini, sejumlah organisasi publik telah menciptakan struktur terpisah yang terlibat dalam pengaturan perjalanan di Uzbekistan. Secara keseluruhan, dalam kerangka implementasi program "Uzbekistan Beylab Sayogat Uil!", Lebih dari 15 juta perjalanan diselenggarakan melalui pariwisata domestik. Sebagai bagian dari menciptakan fasilitas tambahan untuk perjalanan, mulai tahun 2018, dengan keputusan Kepala Negara, prosedur untuk akhir pekan panjang pada hari libur (Tahun Baru, Navruz, Hari Kemerdekaan) pertama kali diperkenalkan.

Faktor-faktor penting yang mempengaruhi tren positif dan hasil signifikan dalam pengembangan sektor pariwisata adalah penyederhanaan rezim visa, aturan untuk tinggal di Uzbekistan dan melakukan bisnis, pengembangan infrastruktur pariwisata dan promosi potensi pariwisata. Menjadi sistem sosio-ekonomi yang kompleks, pariwisata dipengaruhi oleh banyak faktor, yang perannya pada setiap momen dapat berbeda baik dalam kekuatan maupun lamanya dampak terhadap pengembangan pariwisata. Oleh karena itu, akuntansi mereka secara objektif diperlukan untuk organisasi kegiatan pariwisata yang efektif. Aktivitas ekonomi asing dari negara-negara, proses integrasi dan globalisasi yang terjadi di semua tingkatan ekonomi global, yang meliputi formalitas wisata, memiliki pengaruh besar pada bisnis pariwisata.

Formalitas wisata yang terkait dengan lintas batas negara merupakan bagian integral dari pariwisata internasional dan bertindak sebagai fitur utamanya. Semakin banyak hambatan bagi pergerakan bebas orang-orang yang menjadi bagian dari formalitas wisata, memecah belah orang-orang, memiliki dampak signifikan pada pengembangan kontak wisata. 
Faktor-faktor penting yang mempengaruhi pertumbuhan mobilitas wisatawan di Uzbekistan adalah penyederhanaan rezim visa dan peraturan untuk tinggal di Uzbekistan. Pada nomor ini, penting untuk dicatat (tabel-3):

1. Pembentukan tambahan rezim bebas visa untuk 85 negara (hingga 2018, warga negara dari 9 negara: Rusia, Ukraina, Kazakhstan, Azerbaijan, Armenia, Belarus, Georgia, Kirgistan, dan Moldova tidak memerlukan visa untuk memasuki Uzbekistan). Pada bulan Februari 2018, kepala negara menandatangani Keputusan tentang pengenalan rezim bebas visa untuk jangka waktu 30 hari untuk warga negara dari tujuh negara - Israel, Indonesia, Korea Selatan, Malaysia, Singapura, Turki dan Jepang. Pada bulan Maret, Tajikistan ditambahkan ke daftar ini, pada bulan Oktober - Perancis, dari 15 Januari - Jerman, pada tanggal 1 Februari, Uzbekistan memperkenalkan rezim bebas visa selama 30 hari untuk warga negara dari 45 negara lain, mulai 1 Januari 2020 sebuah rezim untuk jangka waktu 30 hari untuk warga negara didirikan 20 negara.

2. Prosedur yang disederhanakan untuk mengeluarkan visa turis untuk warga negara dari 39 negara diperkenalkan (hingga 2018 daftar ini terdiri dari 11 negara). Sistem untuk memproses dan menerbitkan visa masuk elektronik mulai beroperasi pada tanggal 1 Februari 2019, dan daftar negara-negara telah meluas ke 77 negara (57 dalam versi keputusan saat ini), yang warganya dapat memperoleh visa masuk elektronik. Selain itu, mulai 15 Maret 2019, visa entri elektronik ganda dan berganda dengan masa berlaku 30 hari diperkenalkan.

3. Kategori tambahan (non-elektronik) visa masuk telah diperkenalkan untuk kelompok warga negara asing tertentu yang mengunjungi Republik Uzbekistan ("Vatandosh", "visa pelajar", "visa akademik", "visa medis", "visa peziarah" ).

4. Suatu prosedur telah diperkenalkan untuk bebas visa masuk, tinggal sementara dan keberangkatan dari Uzbekistan melalui pos-pos pemeriksaan warga negara 101 (53 dalam versi resolusi saat ini), mengikuti transit melalui wilayah Uzbekistan.

Tabel 3. Jenis rezim visa Republik Uzbekistan yang digunakan untuk tujuan pariwisata

\begin{tabular}{|l|l|l|l|l|}
\hline \multicolumn{1}{|c|}{ Visa } & \multicolumn{1}{|c|}{ Visa-free } & \multicolumn{1}{|c|}{ Transit visa } & $\begin{array}{l}\text { Visa-free entry for } \\
\text { persons under } 16 \\
\text { years of age }\end{array}$ & \multicolumn{1}{|c|}{ E-visa } \\
\hline Mode & 86 & 53 & All countries & 57 \\
\hline $\begin{array}{l}\text { Number of } \\
\text { countries }\end{array}$ & $\begin{array}{l}\text { visa is not } \\
\text { issued }\end{array}$ & $\begin{array}{l}\text { a visa is not } \\
\text { issued, when } \\
\text { applying on the } \\
\text { spot, a stamp is } \\
\text { placed on the } \\
\text { document with } \\
\text { the mark "transit" }\end{array}$ & $\begin{array}{l}\text { visa is not issued } \\
\text { no more than 5 } \\
\text { days }\end{array}$ & $\begin{array}{l}\text { for the validity of the } \\
\text { entry visa in the } \\
\text { passport of the } \\
\text { business days, } \\
\text { not counting the } \\
\text { day of receipt of } \\
\text { documents }\end{array}$ \\
\hline $\begin{array}{l}\text { Terms of } \\
\text { consideratio } \\
\mathrm{n}\end{array}$ & 30 days & $\begin{array}{l}\text { The issued } \\
\text { electronic visa is } \\
\text { valid for } 90 \\
\text { days from the } \\
\text { date of its }\end{array}$ \\
\hline
\end{tabular}


Selain itu, keberhasilan pengembangan pariwisata memerlukan tingkat pengembangan yang memadai dari banyak elemen infrastruktur: jalan raya dan kereta api, bandara, komunikasi, air dan sanitasi, dan listrik.

Infrastruktur pariwisata - seperangkat struktur, bangunan, sistem, dan layanan yang diperlukan untuk berfungsinya pariwisata. Infrastruktur pariwisata adalah kompleks dari struktur dan jaringan yang ada untuk keperluan industri, sosial dan rekreasi, yang dirancang untuk berfungsinya sektor pariwisata

Tren positif dalam arus wisata juga diamati karena penciptaan kondisi yang menguntungkan, manfaat dan preferensi untuk melakukan bisnis, pengembangan infrastruktur di sektor pariwisata.

Untuk menciptakan lapangan kerja baru bagi penduduk setempat, untuk mengembangkan pariwisata ekologis dan pedesaan di negara itu, untuk memperluas jenis layanan yang diberikan kepada wisatawan, pada bulan Agustus prosedur yang disederhanakan untuk mengatur rumah tamu keluarga diadopsi. Jadi, persyaratan sertifikasi dibatalkan dan persyaratan minimum untuk pembuatan rumah tamu ditetapkan. Selain itu, mekanisme alokasi pinjaman preferensial diperkenalkan ketika 50\% dari suku bunga pinjaman ditanggung oleh dana Dana Dukungan Pariwisata. Akibatnya, selama periode terakhir, lebih dari 81 wisma baru mulai beroperasi.

Langkah-langkah yang diambil untuk mendukung dan melindungi sektor swasta berkontribusi pada peningkatan jumlah organisasi pariwisata dari 398 pada 2015 menjadi 950 pada akhir 2018, dan fasilitas hotel dari 661 menjadi 900 unit (Gambar-8).

Dalam rangka menciptakan kondisi tambahan untuk pengembangan infrastruktur transportasi di sektor pariwisata, dengan keputusan pemerintah:

a. Sebuah. bus wisata dibebaskan dari kewajiban untuk mengawal konvoi, asalkan bus ini memenuhi persyaratan keselamatan;

b. Larangan perpindahan bus wisata di malam hari dicabut;

c. praktik kompilasi wajib yang ada oleh badan urusan teritorial dalam laporan inspeksi kendaraan diperbarui sebelum setiap transportasi kelompok wisatawan lokal dibatalkan;

d. Prosedur untuk sertifikasi kendaraan bermotor kelas turis yang diimpor ke republik yang ditujukan untuk pengangkutan 8 orang atau lebih telah disederhanakan.

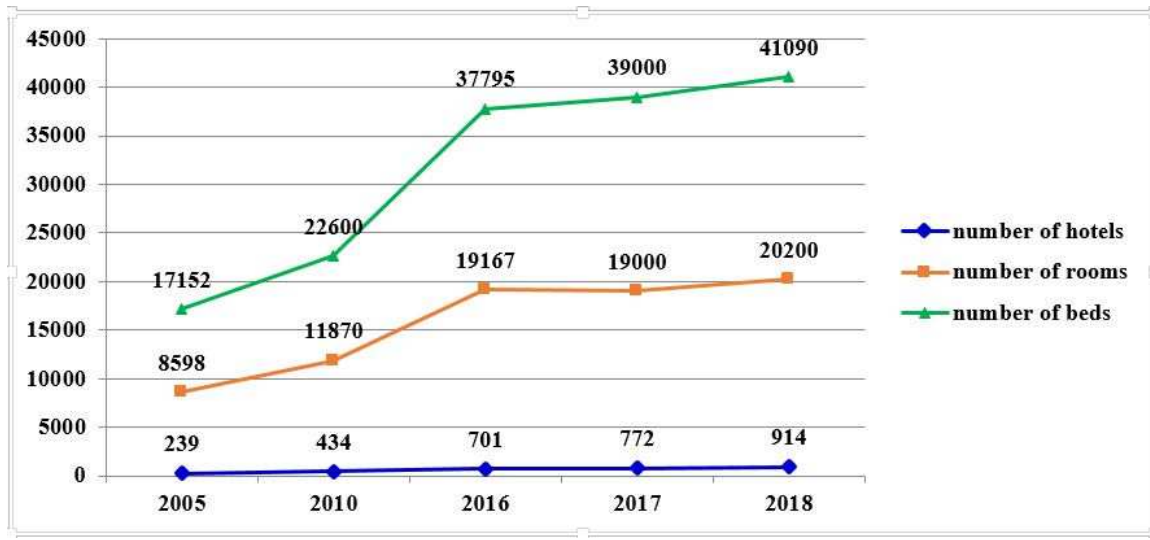

Gambar.-8. Dinamika pengembangan infrastruktur hotel 
Untuk lebih mendiversifikasi produk pariwisata dengan keputusan Kabinet Menteri Republik Uzbekistan, sejumlah waduk dibuka untuk organisasi ekowisata. Pada tahap pertama, direncanakan untuk mengatur ekowisata di 18 waduk yang berlokasi di Andijan, Jizzakh, Kashkadarya, Namangan, Samarkand, Surkhandarya, Tashkent dan wilayah Ferghana.

Untuk mengembangkan wisata ziarah dan mempromosikan potensi negara itu ke negaranegara Asia Tenggara dan, khususnya, Indonesia, Malaysia dan Singapura, penerbangan Tashkent-Jeddah dibuka dengan koneksi ke penerbangan Kuala Lumpur-Tashkent 2 kali seminggu dari 28 Oktober, 2018.

Pada ekonomi pasar, masalah penerapan praktis bentuk modern manajemen personalia dan pelatihan personel yang berkualifikasi di sektor pariwisata merupakan hal yang sangat penting. Orang-orang yang terampil, terlatih, dan termotivasi pada tingkat yang lebih besar menentukan keberhasilan dalam bisnis.

Pencapaian utama pada tahun 2018 ke arah ini adalah diadopsinya Keputusan Presiden Republik Uzbekistan "Tentang Pembentukan Jalur Sutra" Universitas Pariwisata Internasional No. 3815 tanggal 28 Juni 2018. Saat ini, lebih dari 500 siswa sedang belajar di universitas di tiga belas bidang pendidikan studi sarjana dan tiga spesialisasi magistrasi. Kunjungan dilakukan dan negosiasi diadakan dengan lebih dari 55 universitas dari 18 negara terkemuka di dunia yang melatih spesialis di bidang pariwisata, perhotelan, dan layanan.

Hari ini di Uzbekistan ada lebih dari 7 ribu monumen dari berbagai era dan peradaban. Semua harta nasional ini dapat membawa manfaat ekonomi dan sosial ke republik dengan penggunaannya yang terorganisir secara ilmiah dan terarah berdasarkan indikator prakiraan perkembangan pariwisata yang andal di negara tersebut. Kami memutuskan untuk merefleksikan prospek pengembangan pariwisata di Republik Uzbekistan melalui serangkaian indikator kunci yang dinamis (jumlah warga asing yang masuk untuk pariwisata "jumlah pengunjung", jumlah wisatawan asing yang menggunakan layanan dari " jumlah wisatawan asing ") pengembangan pariwisata untuk periode waktu yang sama (tabel 4-6).

Menggunakan paket aplikasi, kami membangun fungsi untuk memperkirakan indikator.

Tabel 4 Fungsi dan parameter ekonomi dan statistik untuk memperkirakan jumlah pengunjung asing ke Republik Uzbekistan.

\begin{tabular}{|c|c|c|}
\hline № & Analytical function & Fisher coefficient \\
\hline 1 & $y=-312,570+278,099 t$ & 20,100 \\
\hline 2 & $y=-542,119+1286,723 \ln (\mathrm{t})$ & 10,182 \\
\hline 3 & $y=1753,280-2975,934 / \mathrm{t}$ & 4,188 \\
\hline 4 & $y=966,112-201,406 \mathrm{t}+31,967 \mathrm{t}^{2}$ & 85,028 \\
\hline 5 & $y=-1003,044+1147,079 t-185,219 t^{2}+9,653 t^{3}$ & 88,619 \\
\hline 6 & $y=401,080^{x} 1,179^{t}$ & 83,430 \\
\hline 7 & $y=277,962 \times \mathrm{t}^{0,891}$ & 83,452 \\
\hline 8 & $y=\mathrm{e}^{(7,798-2,442 / \mathrm{t})}$ & 26,984 \\
\hline 9 & $y=\mathrm{e}^{(5,994+0,165 \mathrm{t})}$ & 83,430 \\
\hline 10 & $y=401,080^{x} \mathrm{e}^{0,165 \mathrm{t}}$ & 83,430 \\
\hline
\end{tabular}

Untuk memprediksi volume layanan pariwisata yang dijual, fungsi yang paling signifikan dan benar adalah fungsi 5 : $\mathbf{y}=\mathbf{- 1 0 0 3 , 0 4 4 + 1 1 4 7 , 0 7 9 t} \mathbf{- 1 8 5 , 2 1 9 t 2 + 9 , 6 5 3 t 3}$, ketika $\mathrm{F}_{\text {табл }}=4,6$ dan $\mathrm{F}_{\text {факт }}=\mathbf{8 8 , 6 1 9}$. 
Tabel 5. Fungsi dan parameter ekonomi dan statistik untuk memperkirakan jumlah wisatawan asing

\begin{tabular}{|c|c|c|}
\hline № & Analytic functions & Fisher coefficient \\
\hline 1 & $y=189,405+34,286 t$ & 25,995 \\
\hline 2 & $y=143,284+168,538 \ln (\mathrm{t})$ & 15,657 \\
\hline 3 & $y=547,179-433,282 / \mathrm{t}$ & 7,809 \\
\hline 4 & $y=299,355-6,945 \mathrm{t}+2,749 \mathrm{t}^{2}$ & 35,691 \\
\hline 5 & $y=33,204+175,315 t-26,606 t^{2}+1,305 t^{3}$ & 37,790 \\
\hline 6 & $y=234,961 \times 1,080^{t}$ & 34,962 \\
\hline 7 & $y=196,563 \times \mathrm{t}^{0,420}$ & 37,682 \\
\hline 8 & $y=\mathrm{e}^{(6,320-1,216 / t)}$ & 24,205 \\
\hline 9 & $y=\mathrm{e}^{(5,459+0,077 \mathrm{t})}$ & 34,962 \\
\hline 10 & $y=234,461 \times \mathrm{e}^{0,077 t}$ & 34,962 \\
\hline
\end{tabular}

Untuk memperkirakan volume layanan pariwisata yang dijual, fungsi yang paling

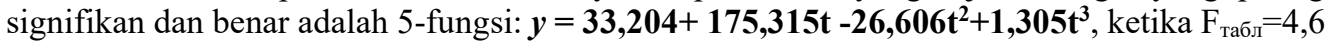
dan $\mathrm{F}_{\text {факт }}=\mathbf{3 7 , 7 9 0}$.

Tabel 6 Indikator ramalan pengembangan pariwisata di Republik Uzbekistan

\begin{tabular}{|c|c|c|c|c|c|}
\hline \multirow{2}{*}{ № } & \multirow{2}{*}{ Name of indexing } & \multirow{2}{*}{$\begin{array}{c}\text { The correct function for } \\
\text { the forecast }\end{array}$} & \multicolumn{3}{|c|}{ years } \\
\hline & & & 2019 & 2020 & 2021 \\
\hline$y_{1}$ & $\begin{array}{l}\text { The number of } \\
\text { foreign visitors to the } \\
\text { Republic of } \\
\text { Uzbekistan, thousand } \\
\text { people }\end{array}$ & $\begin{array}{c}y=-1003,044+ \\
1147,079 t- \\
185,219 t^{2}+9,653 t^{3}\end{array}$ & $\begin{array}{c}7107,7 \\
4\end{array}$ & 9472,84 & 12394,20 \\
\hline$y_{2}$ & $\begin{array}{l}\text { The number of } \\
\text { foreign tourists, } \\
\text { thousand people }\end{array}$ & $\begin{array}{c}y=33,204+175,315 t- \\
26,606 t^{2}+1,305 t^{3}\end{array}$ & $\begin{array}{c}1080,9 \\
5\end{array}$ & 1372,39 & 1735,89 \\
\hline
\end{tabular}

Data dalam tabel menunjukkan peningkatan seragam dalam indikator perkiraan. Pengenalan model yang dikembangkan ke dalam program pengembangan pariwisata di masa depan akan memastikan pengembangan efektif yang konsisten dari industri ini, dengan mempertimbangkan tren pengembangan yang ada di pasar pariwisata nasional.

\section{Kesimpulan}

Kita dapat merumuskan proposal berikut, yang implementasinya akan secara signifikan mempercepat laju pertumbuhan pengembangan pariwisata internasional di tingkat ekonomi nasional Republik Uzbekistan:

a. perusahaan pariwisata perlu mengembangkan wisata sesuai dengan kebutuhan konsumen potensial produk pariwisata nasional;

b. perlu meningkatkan infrastruktur yang diperlukan untuk pengembangan bentuk perjalanan wisata yang tidak terorganisir; 
c. perlu untuk melakukan riset pemasaran berkelanjutan untuk mengidentifikasi preferensi mendalam konsumen dari pariwisata yang tidak terorganisir;

d. perlu mengembangkan strategi pemasaran dengan mempertimbangkan kekhasan tren pengembangan pariwisata internasional;

e. kebutuhan untuk membentuk sumber informasi yang terintegrasi, yaitu, basis informasi wisatawan dan sistem informasi interaktif untuk penggunaannya;

f. program pariwisata di wilayah tersebut harus konsisten dengan perubahan geografi kunjungan dengan tujuan wisata untuk Republik Uzbekistan dalam beberapa tahun terakhir.

\section{References}

[1] J. Ritchie, "Assessing the impact of hallmark events: Conceptual and research issues," J. Travel Res., vol. 23, no. 1, hlm. 2-11, 1984.

[2] Y.-S. Wang, The impact of crisis events and macroeconomic activity on Taiwan's international inbound tourism demand Tourism Management, vol. 30. 2009.

[3] E. Smeral, H. Song, S. Lin, M. Mar Alonso-Almeida, K. Bremser, dan Y.-S. Wang, "The impact of the financial and economic crisis on European tourism," J. Travel Res., vol. 48, no. 1, hlm. 3$13,2009$.

[4] W. Jennings dan P., "Governing the games in an age of uncertainty: The Olympics and organisational responses to risk," Terror. Olymp. Major Event Secur. Lessons Future, vol. 12, hlm. 135-162, 2010.

[5] M. Uysal dan J. Crompton, "An overview of approaches used to forecast tourism demand," $J$. Travel Res., vol. 23, no. 2, hlm. 7-15, 1985.

[6] F. Chu, "Forecasting tourist arrivals, non linear sine wave or ARIMA?," J. Travel Res., vol. 36, no. 3, hlm. 79-84, 1998.

[7] A. Bassolas, M. Lenormand, A. Tugores, B. Gonçalves, dan J. J. Ramasco, "Touristic site attractiveness seen through Twitter,” EPJ Data Sci., vol. 5, no. 1, hlm. 10-1140, 2016.

[8] R. Calantone, A. Benedetto, dan D. Bojanic, "A comprehensive review of tourism forecasting literature," J. Travel Res., vol. 16, no. 3, hlm. 28-39, 1987. 